\title{
Grouping of beta-haemolytic streptococci with group-specific antibodies adsorbed to staphylococcal protein A
}

\author{
G. M. TEBbUTT, D. J. COLEMAN, AND D. MCGHIE \\ From the Regional Public Health Laboratory, East Birmingham Hospital, Birmingham B9 5ST
}

SYNOPSIS A total of 245 isolates of beta-haemolytic streptococci was grouped by the countercurrent immunoelectrophoresis method and by co-agglutination with antibody-coated staphylococci. Co-agglutination was found to be simple and accurate, and many commerically available grouping sera were suitable for use in this test, though some of them had to be absorbed to remove crossreactions.

The majority of human diseases caused by betahaemolytic streptococci are attributed to Lancefield group A strains, but strains belonging to group B are an important cause of neonatal meningitis and sepsis (Horn et al, 1974). Groups C and G streptococci also cause disease (Hill et al, 1969; Finnegan et al, 1974) and the possibility that these groups cause nephritis is under investigation (Belcher et al, 1975). It is important that laboratories continue to differentiate group A strains from other beta-haemolytic streptococci, and it is highly desirable that strains belonging to the other common groups should be identified and any changes in epidemiological patterns or drug resistance recognized.

Serological grouping of beta-haemolytic streptococci can be performed by extracting the groupspecific carbohydrates and producing a precipitate against a group-specific antiserum either in capillary tubes (Lancefield, 1933) or by the counter-current immunoelectrophoresis (CIE) method (Edwards and Larson, 1973). However, these are laborious as routine tests. Recently, Christensen et al (1973) showed that group-specific antistreptococcal antibody could be bound to staphylococci via the protein A cell wall component. When trypsinized streptococci of the corresponding group were added, specific co-agglutination occurred with the antibody-coated staphylococci (protein A method).

The present study was undertaken to find out if commercially available grouping sera could reliably be used to identify beta-haemolytic streptococci of groups $\mathbf{A}, \mathbf{B}, \mathbf{C}, \mathbf{D}$, and $\mathbf{G}$ in a routine laboratory.

Received for publication 5 April 1976

\section{Material and methods}

STREPTOCOCCAL STRAINS

Strains of streptococci which showed beta-haemolysis on $5 \%$ horse blood Columbia agar (Oxoid) after overnight aerobic growth at $37^{\circ} \mathrm{C}$ were collected and stored on $10 \%$ blood agar slopes. A total of 245 strains was studied.

STREPTOCOCCAL GROUPING SERA

Rabbit antisera against streptococcal group antigens A, B, C, D, and G were purchased from Wellcome Laboratories, Beckenham, Kent, and antisera against $\mathbf{A}$ and $\mathbf{B}$ antigens were obtained from Difco Laboratories, West Molesey, Surrey. When necessary, $0.3 \mathrm{ml}$ of grouping serum was absorbed for $1 \mathrm{~h}$ at $37^{\circ} \mathrm{C}$ with $0.1 \mathrm{ml}$ (packed cell volume) of trypsinized and washed streptococci.

\section{GROUPING OF STREPTOCOCCI BY COUNTER-} CURRENT IMMUNOELECTROPHORESIS

Streptococcal antigen extracts were prepared by the autoclave method of Rantz and Randall (1955) and were tested against Wellcome group-specific antisera by CIE (Edwards and Larson, 1973).

\section{GROUPING OF STREPTOCOCCI WITH}

ANTIBODY-COATED STAPHYLOCOCCI

The method was similar to that described by Christensen et al (1973). The Cowan I strain of Staphylococcus aureus (NCTC No. 8530) was grown overnight in Trypticase Soy Broth (Baltimore Biological Laboratories), and the bacteria were washed five times in PBS (0.03 M phosphate pH 7.3, 1085 
$0.12 \mathrm{M} \mathrm{NaCl}$ with $0.1 \%$ sodium azide as preservative). The bacteria were suspended in $0.5 \%$ formaldehyde in PBS for $3 \mathrm{~h}$ at room temperature, washed twice in PBS, and made up to a concentration of $10 \%$ in PBS. This suspension was heated to $80^{\circ} \mathrm{C}$ in a water-bath for $30 \mathrm{~min}$, and the bacteria were washed three times in PBS and stored at a final concentration of $10 \%$. One millilitre of this suspension was added to $0.1 \mathrm{ml}$ of specific rabbit antiserum and the mixture was incubated for $1 \mathrm{~h}$ at $37^{\circ} \mathrm{C}$. The antibody-coated staphylococci were washed and suspended to $1 \%$ in PBS. Generally, Wellcome grouping sera were used, but for streptococcal groups $A$ and B Difco sera were also tested.

For each test a sweep of streptococcal colonies was emulsified in $0.4 \mathrm{ml}$ Tris buffer (tris (hydroxymethyl) aminomethane, $0.03 \mathrm{M} \mathrm{pH} \mathrm{8.1)} \mathrm{and} 0.1 \mathrm{ml}$ of either 5 or $10 \mathrm{mg} / \mathrm{ml}$ trypsin (Sigma) was added to give a final trypsin concentration of 1 or $2 \mathrm{mg} / \mathrm{ml}$. The suspension was agitated on a Vortex mixer for $5 \mathrm{~s}$ and then incubated for $1 \mathrm{~h}$ at $37^{\circ} \mathrm{C}$. A $4 \mathrm{~mm}$ loopful of trypsinized streptococcal suspension was mixed with a loopful of antibody-coated staphylococcal reagent on a microscope slide. The slide was rocked continuously for $30 \mathrm{~s}$ and examined for co-agglutination. To avoid bias in the interpretation of these tests they were read by one of us (GMT) without prior knowledge of the identity of the streptococci.

\section{Results}

Comparative results of grouping 245 isolates of streptococci by CIE and by the protein A method are shown in table I. Generally antisera were used without absorption, but the identification of groups $B$ and $G$ streptococci by co-agglutination was possible only when group B antiserum (Difco) was absorbed with trypsinized group $\mathrm{G}$ streptococci and the group $G$ antiserum (Wellcome) was absorbed with trypsinized group B streptococci.

A total of 128 group A strains was identified by $\mathrm{CIE}$ and by co-agglutination with anti-group $\mathrm{A}$ staphylococcal reagent; the group A co-agglutina-

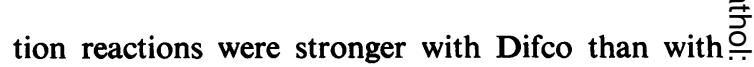
Wellcome antiserum. Five group A strains also re- $\overrightarrow{\vec{F}}$ acted with staphylococci coated with antibody $\stackrel{?}{+}$ against group B streptococci, and the group A coagglutination reactions of these strains were not as $\frac{\bar{c}}{\bar{c}}$ strong as with other group A streptococci. Absorp- $\frac{\vec{\sigma}}{0}$ tion of group B antiserum with trypsinized suspen- $\varrho$ sions of three of the five strains removed or markedly reduced the reactions of all five against anti-group $B \vec{\circ}$ staphylococcal reagent (table II). This suggests that absorbed group B antiserum might permit the $\vec{\omega}$ identification of other group A streptococci which $\frac{O}{2}$ give group A and B cross-reactions. The group A co-o agglutination reactions of these five strains were 0 slightly stronger if the streptococci were treated with $\vec{N}$ $2 \mathrm{mg} / \mathrm{ml}$ trypsin (see Methods) or if the staphylo- coccal reagent was prepared with $0.2 \mathrm{ml}$ instead of $\circ$ $0.1 \mathrm{ml}$ of group A antiserum per $\mathrm{ml}$ staphylococcal $\mathrm{O}$ suspension.

Twenty-seven group B strains were found by $\mathrm{CIE}_{\vec{\sigma}}^{-}$ and were correctly identified by co-agglutination $\mathbb{D}$ with anti-group B staphylococcal reagent using $\mathbb{S}$ Difco antiserum (table I). Wellcome grouping serumo gave weak co-agglutination with group B strepto- $\stackrel{D}{-}$ cocci and was not satisfactory for their identificatiog. $\vec{\bullet}$ Cross-reactions of Difco group B antiserum wi ho

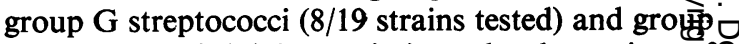
A streptococci (5/128 strains) made absorption aff

\begin{tabular}{lccc} 
Group A strains & \multicolumn{3}{c}{ Reactions with antibody-coated staphylococci } \\
& & B & B abs \\
$\mathbf{5 6}$ & A & ++ & - \\
$\mathbf{5 8}$ & $++^{2}$ & ++ & + \\
$\mathbf{2 2 0}$ & ++ & ++ & - \\
$\mathbf{2 8 6}$ & + & ++ & - \\
& ++ & ++ & - \\
\hline
\end{tabular}

Table II Cross-reactions of five group $A$ streptococci with group $B$ antiserum

${ }^{1}$ Grouping sera: A (Difco or Wellcome), B (Difco), and B abs (Difco absorbed with group A streptococci (strains 56, 220, and 286)).

${ }^{2}$ Co-agglutination ++ strong, + weak, - absent.

\begin{tabular}{|c|c|c|c|c|c|c|c|c|}
\hline \multicolumn{2}{|l|}{$C I E^{1}$} & \multicolumn{7}{|c|}{ Reactions with staphylococci ${ }^{2}$ coated with antibody of group: } \\
\hline Group & Positive & $A$ & $\boldsymbol{B}$ & $C$ & $D$ & $\boldsymbol{G}$ & Total positive & No reaction \\
\hline$\overline{\mathbf{A}}$ & 128 & 128 & $(5)$ & 0 & 0 & 0 & $128+(5)$ & $\mathbf{0}$ \\
\hline B & 27 & 0 & 27 & 0 & 0 & 0 & 27 & 0 \\
\hline $\mathrm{C}$ & 46 & 0 & 0 & 45 & 0 & 0 & 45 & 1 \\
\hline $\mathbf{D}$ & 11 & 0 & 0 & 0 & 11 & 0 & 11 & 0 \\
\hline$G$ & 33 & $\mathbf{0}$ & (1) & $\mathbf{0}$ & 0 & 31 & $31+(1)$ & 2 \\
\hline
\end{tabular}

Table I Comparison of grouping of 245 isolates of streptococci by CIE and by protein A method

${ }^{1}$ Tested against unabsorbed 'Wellcome' grouping sera.

${ }^{2}$ Grouping sera were A (Difco or Wellcome), B (Difco) absorbed with group G streptococci, C (Wellcome), D (Wellcome), and G (Wellcome) absorbed with group B streptococci.

Brackets denote cross-reactions; five group $A$ and one group $G$ strain reacted with absorbed group B antiserum. 
this antiserum necessary. After absorption, one group $A$ and one group $G$ strain showed weak reactions but these were easily distinguished from the specific co-agglutination. None of the 27 group B strains tested gave cross-reactions with anti-group A staphylococcal reagent.

Tests for co-agglutination of streptococci belonging to groups $C, D$, and $G$ with antibody-coated staphylococci were done with Wellcome grouping sera. Forty-six group $\mathrm{C}$ and 33 group $\mathrm{G}$ streptococci were identified by CIE. Of these, one group $C$ and two group $G$ streptococci failed to react when tested by the protein $A$ method but other group $C$ and $G$ streptococci were correctly identified. Eleven betahaemolytic group D streptococci were found by CIE and all gave specific co-agglutination with antigroup D staphylococcal reagent.

\section{Discussion}

Specific co-agglutination with antibody-coated staphylococci has been successfully used by Christensen et al (1973) to identify streptococcal groups A, B, C, D, and G but they considered most commercially available grouping sera unsuitable for the preparation of group-specific staphylococcal reagent. This meant that the method could not be directly applied for routine use in diagnostic laboratories. In this study five grouping sera from Wellcome and two sera from Difco were used (see Methods) and only Wellcome group B antiserum failed to give strong co-agglutination. The batches of Difco and Wellcome group A antisera that we tested could be used reliably without absorption to screen for group A streptococci. Cross-reactions were observed with two group-specific antisera (Difco B and Wellcome G) but absorption with strains of the cross-reacting streptococcal groups permitted reliable identification. Before routine use in the protein A method, therefore, grouping sera should be tested with streptococci of heterologous groups, and cross-reactions removed by suitable absorption.

One problem encountered by us was the crossreactivity of five group A streptococci (5/128 strains) with anti-group B staphylococcal reagent. In contrast to this finding, other workers have found that Difco group B antiserum gave clear-cut and specific co-agglutination reactions (Christensen et al, 1973). However, relatively few group A streptococci have been studied by the protein A method, and it seems reasonable to suggest that the testing of more group A strains against different batches of Difco group B antiserum is needed to determine the extent and relative importance of these cross-reactions. The five group A strains described here were easily identified because they showed typical group A colonial morphology on blood agar, were sensitive to bacitracin, and autoclave extracts of them gave clear-cut specific precipitin reactions with group $\mathrm{A}$ antiserum.

The protein A method described here is reliable, simple, and inexpensive. The initial cost of streptococcal grouping sera is offset by the fact that only a small quantity of serum is required per test; theoretically $1 \mathrm{ml}$ of grouping serum is sufficient for about 7000 tests. This makes the method considerably cheaper than the commercial kit now available. A comparison of the protein A and the CIE methods indicates that the degree of reliability is similar. The advantages of the protein $\mathrm{A}$ method are that it requires minimal time and no special apparatus, and costs very little.

We wish to thank Dr W. R. Maxted and Dr J. G. P. Hutchison for advice and criticism during the preparation of this paper. We also thank Mrs V. A. Whittaker for secretarial help.

\section{References}

Belcher, D. W., Afoakwa, S. N., Osei-Tutu, E., Wurapa, F. K., and Osei, L. (1975). Non-group-A streptococci in Ghanaian patients with pyoderma. (Letter). Lancet, 2, 1032.

Christensen, P., Kahlmeter, G., Jonsson, S., and Kronvall, G. (1973). New method for the serological grouping of streptococci with specific antibodies adsorbed to Protein $\mathrm{A}-$ containing staphylococci. Infect. and Immun., 7, 881885.

Edwards, E. A. and Larson, G. L. (1973). Serological grouping of hemolytic streptococci by counter immunoelectrophoresis. Appl. Microbiol., 26, 899-903.

Finnegan, P., Fitzgerald, M. X. M., Cumming, G., and Geddes, A. M. (1974). Lancefield group C streptococcal endocarditis. Thorax, 29, 245-247.

Hill, H. R., Caldwell, G. G., Wilson, E., Hager, D., and Zimmerman, R. A. (1969). Epidemic of pharyngitis due to streptococci of Lancefield group G. Lancet, 2, 371-374.

Horn, K. A., Meyer, W. T., Wyrick, B. C., and Zimmerman, R. A. (1974). Group B streptococcal neonatal infection. J. Amer. med. Ass., 230, $1165-1167$.

Lancefield, R. C. (1933). A serological differentiation of human and other groups of hemolytic streptococci. J. exp. Med., 57, 571-595.

Rantz, L. A. and Randall, E. (1955). Use of autoclaved extracts of hemolytic streptococci for serological grouping. Stanf. med. Bull., 13, 290-291. 